\title{
INNOVATION FOR EMPOWERMENT OF WAQF LAND RIGHT: COMPARATIVE ANALYSIS OF LEGAL ASPECTS OF WAQF LAND AND LAND WITH RIGHT OF MANAGEMENT IN INDONESIA
}

\author{
Lutfi Djoko Djumeno', Fahrul Fauzi *2 \\ ${ }^{1}$ Alumni of Faculty of Law \& Master of Management University of Indonesia, Jl. Intan \\ Ujung C11, Cilandak Barat, South Jakarta 12430, lutfidjoko@gmail.com. \\ ${ }^{2}$ Faculty of Law University of Indonesia, Jl. Prof. Mr Djokosoetono, Pondok Cina, Beji, \\ Depok, West Jawa 16424, ffahrul107@gmail.com.
}

*Corresponding author: ffahrul107@gmail.com

(Received: $15^{\text {th }}$ September 2021; Accepted: $28^{\text {th }}$ November 2021; Published: $31^{\text {st }}$ December 2021)

\section{Keywords:}

Waqf; Waqf Land;

Right of Management; Land Rights;Indonesia;

\begin{abstract}
A B S T R A C T
The existence of waqf institutions in Indonesia has the potential to be developed, considering that Indonesia is a country with the largest Muslim population in the world. One of the most common waqf objects is waqf land. Currently, waqf land in Indonesia is relatively not used productively. The current use of waqf land is mostly limited to mosques, tombs, and madrasas. This paper provides an innovation on the management of waqf land that has not been productive in the form of giving land rights on the waqf land. The research method used in writing this article is normative legal research. This study uses primary legal materials namely Law No. 41 of 2004, Law No. 11 of 2020, and Government Regulation No. 18 of 2021. This study found a point of similarity
\end{abstract}


between the concept of waqf land and land with right of management. Indonesian Land Law recognizes various kinds of land rights, such as right of ownership, right of cultivation, right of building, and right of use. Land with right of management can be granted on it, the right of cultivation and the right of building. Waqf land which has a similar concept with right of management should also be given land rights such as right of cultivation, right of building, and also right of use. This concept can provide benefits for developers, nazhir, and the Ummah. Developers get benefits in the form of freedom in land acquisition costs and can guarantee their land rights. Then, nazhir benefits in the form of land use fees and a recommendation fee from the developer. The profits received by nazhir can then be used for the welfare of the people according to the waqf pledge.

Publisher All rights reserved.

\section{INTRODUCTION}

Islam is a religion that regulates human life comprehensively. Besides regulating the vertical relationship between humans and their God, Islam regulates the horizontal relationship between humans. One example of a teaching that regulates horizontal relationships is waqf. Waqf institution involves social dimension. Not infrequently, the benefits are not only felt by followers of the Islamic religion but can also be felt by the general public.

The word waqf comes from Arabic, which is taken from the word "waqofa-yaqifu-waqfan", which means "hesitating, stopping, dismissing, understanding, preventing, holding back, saying, showing, putting, paying attention, serving, and standing still." (Munawwir, 1984). Abdul Wahhab Khallaf, in the book Ahkam al-Waqf, defines waqf as holding something both hissi (which can be felt by the five senses) and meaning (abstract). Muhammad Ibn Ismail as-San'any mentions that waqf has the meaning of holding property that may be taken advantage of without spending or destroying the object and using it for good thing. (Prihatini, 2005).

A Muslim can use waqf as a means of distributing excess sustenance that Allah SWT has given. Useful waqf property will become an unbroken charity, even after death (Faizin, 2017).

The development of waqf and the spread of Islam in Indonesia go hand in hand. In the past, waqf objects were identical to immovable objects such as land and buildings. This can be seen from the number of 
waqf assets in mosques, Islamic boarding schools, and madrasas. The waqf property helped the efforts of the ulama at that time in spreading the teachings of Islam in Indonesia.

As a country with the largest Muslim population in the world, Indonesia strongly supports the existence of waqf. The initiatives of waqf can be seen from the government's concrete support by establishing Law Number 41 of 2004 concerning Waqf (Waqf Law). The Waqf Law defines waqf as a legal act of wakif to separate and/or hand over part of his property to be used forever or for a certain period following his interests for worship and/or general welfare according to sharia.

The Waqf Law accommodates new forms of waqf objects such as cash waqf, precious metal waqf, securities waqf, and so on. The development of new waqf objects does not mean that the old waqf objects are forgotten. Land as an object of waqf that has existed for a long time has become essential to be optimized. According to Mohammad Nuh, the potential of waqf assets in Indonesia per year reaches Rp. 2,000 trillion with a waqf land area of 420 thousand hectares. Even data released by the Ministry of Religion indicates that the potential for waqf in Indonesia is the largest in the world $(161,579$ hectares of waqf land and cash waqf penetrates Rp. 188 trillion per year) (Nuh, 2019).

Base on the statistical data, it is regrettable if the vast and strategic potential of waqf land is not used productively or even abandoned. The Waqf Council and ZIS PP Muhammadiyah once issued a Fatwa Tarjih (Ulama's Decision) regarding abandoned waqf land, namely that there are two main problems that caused waqf land to be neglected. First, the absence of fund to fulfill the intention of the waqif. Second, there are already similar facilities in the vicinity hence, it does not a priority to materialise the intention of the waqif at the moment, as it does not fulfill the the need of the public (Hidayati, 2010).

This article provides an idea to prevent abandoned land problems due to the unavailability of funds for waqf optimization. Optimization of waqf land can be done by granting land rights for the use or development of the waqf land. As such, any proposal for the construction of apartments or shopping centers is not difficult to accomplish if this concept can be applied on waqf land. The land rights can be in the form of Right of Building, Right of Cultivation, and Right of Use. The granting of land rights on the waqf land was inspired by the granting of rights on land with the right of management. In this study, waqf land and land with the right of management will be the focus of the discussion because they have similarities from the legal perspective (Islam, 2013).

The research method used in this article is a normative legal research method. Researchers only use library materials or secondary data in normative legal research consisting of primary legal materials, secondary legal materials, and tertiary legal materials that regulate or discuss waqf land (Soekanto, 1986). The primary legal materials that form the basis of this research are the Waqf Law, Law Number 5/1960 concerning Basic Regulations on Agrarian Principles (Basic Agrarian Law), Law Number 
11/2020 concerning Job Creation (Job Creation Law), and Government Regulation Number 18/2021 concerning Right of Management, Land Rights, Flat Units, \& Land Registration.

The technical analysis of the data used in this research is the technical analysis of qualitative data. The author writes by organizing the data obtained from the legal material that is the source of this writing (Jalil, 2020). Then sort it into manageable units, synthesize, search and find patterns, find something meaningful to learn, and decide what can be written down so that it is easy to understand (Moleong, 2017).

This article aims to provide an idea or innovation in realizing the granting of land rights on waqf land to increase the optimization of waqf land. If the concept of granting land rights on waqf land can be applied, it can add value to the waqf land assets without eliminating the fundamental essence of the waqf itself. This paper is also expected to be the basis and guide for policy developers in Indonesia in formulating legislation on waqf, especially the empowerment of waqf land in the future.

\section{PART I - LAND WITH RIGHT OF MANAGEMENT AND LAND RIGHTS IN INDONESIA}

Regulations on land tenure may differ in each country. For example, there are differences between land tenure systems in Indonesia, Malaysia, Singapore, and Australia. The fundamental thing that most distinguished is the principle of land and building ownership. Land law in Malaysia, Singapore, and Australia, which is based on English Common Law, uses the principle of accessie (attachment). Meanwhile, land law in Indonesia is based on customary law using the principle of horizontal scheiding (horizontal separation) (Sumanto, 2013). The essence of the difference is that the principle of attachment of the land owner must be the owner of the building above it, in contrast to horizontal separationwhich does not necessarily mean that the owner of the building is also the owner of the land below it. Due to the significant differences between Indonesian land law and other countries, this article will briefly explain the land rights that are regulated in the Indonesian Land Law.

\section{Legal Aspect of the Right of Management}

Implicitly in Article 2 paragraph (4) of the Basic Agrarian Law states that the implementation of the State's right of control can be delegated to autonomous regions and customary law communities, just as needed and not contradicting national interests and following statutory regulations. There is a possibility to issue a new right whose name has not been mentioned in the Basic Agrarian Law but is a delegation of implementation to autonomous regions and customary law communities. This delegation of authority is known as the Right of Management.

Boedi Harsono revealed that the existence of the right of management in Indonesian Land Law is not mentioned in the Basic Agrarian Law but is implied in General Elucidation II point (2) of the Basic Agrarian Law: "The state can give such land to a person or entity with a right according 
to its designation and needs, for example, with a right of ownership, right of cultivation, right of building, or right of use or give it under management to a Ruling Body (Department, Bureau, or Autonomous Region) to be used for the implementation of their respective duties". Furthermore, he argues that the right of management in the systematic land tenure rights are not included in the category of land rights. The holder of the right of management does have the authority to use the land acquired for his business purposes, but that is not the purpose of granting the right. The purpose of granting the right of management is to provide the land in question for use by other parties who need it.

Holders of the right of management in the implementation of granting land rights have the authority to carry out activities that are part of the authority of the State as referred to in Article 2 of the Basic Agrarian Law. More emphatically, Boedi Harsono stated that the right of management is not essentially land rights but is a 'piece' of the State's right of control. Similarly, Maria Sumardjono said that the management right is a 'part' of the State's right of control whose authority is delegated to the holder (Sumardjono, 2008).

The latest definition of the right of management is regulated in Government Regulation Number 18 of 2021, namely the State's right of control, whose implementation authority is partially delegated to the holder of the Right of Management. The right of management can come from state land or customary land. The right of management on the state land may be given to several legal subjects, including central government agencies, regional governments, state/regional-owned enterprises, state/regional-owned legal entities, land bank entities, legal entities appointed by the government.

Article 7 Government Regulation Number 18 of 2021 states that the holder of the right of management is given the authority: a. make a plan for land allocation, use, and utilization following the spatial plan; $b$. use and utilize all or part of the land with management rights for own use or cooperation with other parties; c. determine the rate or annual mandatory fee from the other party following the agreement.

The right of management involving theuse and utilize all or part of the land for their use or cooperation with other parties may be granted land rights. It is either in the form of right of cultivation, right of building, and right of use on the right of management, according to their nature and function to the right of management holders or other parties with a landuse agreement.

\section{Land Rights in Indonesia}

Land rights in Indonesia vary widely, and it may be difficult for foreigners to understand the difference. Legal subjects can own land rights according to their designation. For example, land for agricultural purposes is given land rights in the form of the right of cultivation, land for offices is given land rights in the form of the right of building, and many other examples. The situation is different from the types of land rights in neighboring 
countries, which can be considered simple. For example, in Malaysia, Article 40 of the National Land Code (Act 56 of 1965) states that "all state land belongs to the State authority." As the state is the owner, then the transfer of land rights to other parties may appear as freehold title and leasehold title.

The regulation of land rights in Indonesia is not as simple as in Malaysia or other countries. If a hierarchy of levels is formed regarding land tenure rights, it can be arranged as follows:

\begin{tabular}{|c|c|c|}
\hline No & $\begin{array}{l}\text { Types of Land } \\
\text { Tenure }\end{array}$ & Explanation \\
\hline 1 & $\begin{array}{l}\text { Indonesian } \\
\text { Nation's Rights }\end{array}$ & $\begin{array}{l}\text { This means that all land included in the } \\
\text { territory of the Republic of Indonesia belongs } \\
\text { to the Indonesian people. }\end{array}$ \\
\hline 2 & $\begin{array}{l}\text { The State's Right } \\
\text { of Control }\end{array}$ & $\begin{array}{l}\text { As the highest authority organization, the } \\
\text { state is given the task by Indonesian land law } \\
\text { to be able to control or direct the functions of } \\
\text { the earth, water, and space according to } \\
\text { government policy. }\end{array}$ \\
\hline 3 & $\begin{array}{l}\text { Customary Land } \\
\text { of Customary Law } \\
\text { Community }\end{array}$ & $\begin{array}{l}\text { The authority and obligations of a customary } \\
\text { law community relating to land located } \\
\text { within its environment. This recognition of } \\
\text { customary land (hak ulayat) continues as } \\
\text { long as, in reality, it still exists. }\end{array}$ \\
\hline 4 & Individual Rights & $\begin{array}{l}\text { Consist of: } \\
\text { (1) primary land rights (sourced directly } \\
\text { to the rights of the Indonesian } \\
\text { nation) include: } \\
\text { a. right of ownership } \\
\text { b. right of cultivation } \\
\text { c. right of building } \\
\text { d. right of use on the state land } \\
\text { (2) secondary land rights (which do not } \\
\text { originate directly from the rights of } \\
\text { the Indonesian people) include right } \\
\text { of building and rights of use on the } \\
\text { right of ownership, right of lease, } \\
\text { right of lien, right of production- } \\
\text { sharing endeavour, right of transient } \\
\text { occupancy, etc. }\end{array}$ \\
\hline 5 & Waqf Land Rights & $\begin{array}{l}\text { Individual land rights that have been pledged } \\
\text { for waqf purposes and granted waqf land } \\
\text { certificates. }\end{array}$ \\
\hline 6 & $\begin{array}{l}\text { Encumbrance } \\
\text { Right Over Land }\end{array}$ & $\begin{array}{l}\text { Shall be the security right under which a land } \\
\text { title is placed as stipulated in Basic Agrarian } \\
\text { Law, with or without other objects forming } \\
\text { united with the land, for particular creditor }\end{array}$ \\
\hline
\end{tabular}




\section{\begin{tabular}{|l|l|}
\hline & over other creditors.
\end{tabular} \\ Table 1: Hierarchy of Land Tenure Rights in Indonesia \\ Source: Boedi Harsono on Indonesian Agrarian Law, History of the Formation of Basic Agrarian Laws, Content and Implementation}

Land with the right of management can be granted land rights in the form of right of cultivation, right of building, and right of use. Therefore, the detailed explanation of land rights in this article focuses more on these three rights.

The Basic Agrarian Law defines the right to cultivation as the right to cultivate land that the State directly controls for 35 years for agricultural, fishery or livestock companies. At the request of the rights holder and considering the company's condition, the period can be extended for a maximum period of 25 years. Legal subjects who can control land with usufructuary rights are Indonesian citizens and legal entities established under Indonesian law. In the past, the right of cultivation could only be granted on state land directly, but the current development is Law Number 11 of 2020 concerning job creation allows the right of cultivation to be built on land with the right of management. The right of cultivation on the right of management is granted by the decision of the Minister based on the approval of the right of management holder.

The right of building is the right to construct and own buildings on land that is not one's own, with a maximum period of 30 years. At the right holder's request and taking into account the needs and condition of the buildings, the period may be extended for a maximum period of 20 years. Legal subjects who can control building use rights are Indonesian citizens and legal entities established under Indonesian law. The right to use this building can be granted on state land, land with the right of ownership, or land with the right of management.

The right of use is the right to use or collect the proceeds from land directly controlled by the state or land owned by another person. They are giving the authority and obligations specified in the decision to grant it by the official authorized to provide it with or in an agreement with the owner of the land, which is not a lease agreement or land management agreement. The right of use can also be granted on the right of management. The right of use consists of the right of use with a period and the right of use as long as it is used. The right of use with a period can be owned by Indonesian citizens, Indonesian legal entities, foreign legal entities, religious/social entities, and foreigners. The right of use as long as it is used can be granted to central government agencies, regional governments, village governments, representatives of foreign countries, and representatives of international agencies. These three rights can be granted on the right of management. If the right of management has legal aspects similar to waqf land, it is questionable why rights over the land cannot be granted on waqf land. Furthermore, it will discuss the innovation of granting land rights on waqf land by considering the similarity of legal aspects of the right of management and waqf land. 


\section{PART II - INNOVATION FOR GRANTING LAND RIGHTS ON WAQF LAND}

Waqf land in Indonesia is a very strategic object if it is optimally beneficial. This innovation is an effort to prevent waqf land from being neglected or even abandoned. The granting of land rights on waqf land is an innovation. As an innovation, there will undoubtedly be conflict with the old concepts that are currently applied. Therefore, all inputs and suggestions for this innovation are very welcome.

The concept of productive waqf can be applied in waqf land. One of the concepts that can be applied to become a productive waqf land is granting land rights on waqf land. The granting of land rights will not eliminate the status of the waqf land itself, but rather the rights to land that are born standing on waqf land so that when the term of land rights expires, the land returns to be waqf land managed by nazhir. This concept is a productive waqf concept that can be a solution for waqf lands that are still mostly managed consumptively or even neglected.

Analysis of the Similarity of Land with the Right of Management and Waqf Land (Legal Perspective)

Boedi Harsono stated that in terms of the authority to control, state lands could be broken down as follows: (Harsono, 2018).

a. Waqf Land

b. Land with the Right of Management

c. Customary Land

d. Community Land

e. Forest Area Lands.

f. Remaining Lands (state land in a narrow sense)

In terms of the control authority above, it can be seen that both rights of management and waqf land are details of state land. Therefore, why only on land with the right of management can other land rights be granted? Why can't waqf land?

The similarities in legal aspects between waqf land and land with management rights can also be seen in terms of the following aspects:

\begin{tabular}{|l|l|l|l|}
\hline No & Indicator & Waqf Land & $\begin{array}{l}\text { Land with Right of } \\
\text { Management }\end{array}$ \\
\hline 1 & Land tenure & $\begin{array}{l}\text { It is a breakdown of } \\
\text { state lands. }\end{array}$ & $\begin{array}{l}\text { It is a breakdown of } \\
\text { state lands. }\end{array}$ \\
\hline 2 & Proof of rights & $\begin{array}{l}\text { Proof of title by } \\
\text { issuing a certificate } \\
\text { (waqf land } \\
\text { certificate). }\end{array}$ & $\begin{array}{l}\text { Proof of title by issuing } \\
\text { certificate (right of } \\
\text { management } \\
\text { certificate). }\end{array}$ \\
\hline 3 & Characteristics & $\begin{array}{l}\text { Waqf land cannot be } \\
\text { transferred. }\end{array}$ & $\begin{array}{l}\text { Land with the right of } \\
\text { management cannot be } \\
\text { transferred }\end{array}$ \\
\hline
\end{tabular}




\begin{tabular}{|l|l|l|l|}
\hline & & & \\
\hline 4 & Land manager & Nazhir. & $\begin{array}{l}\text { Central government } \\
\text { agencies, regional } \\
\text { governments, } \\
\text { state/regional-owned } \\
\text { enterprises, } \\
\text { state/regional-owned } \\
\text { legal entities, land bank } \\
\text { entities, and legal } \\
\text { entities appointed by the } \\
\text { government. }\end{array}$ \\
\hline
\end{tabular}

Table 2: Similarities in Legal Aspects of Waqf Land \& Land with the Right of Management

It can be concluded that both waqf land and land with the right of management are more detailed than land directly controlled by the state, as stated by Boedi Harsono. Both waqf land and land with the right of management can be issued with a certificate. In terms of their characteristics, they are neither transferable. The management, maintenance, and development of the two lands are also carried out by parties determined by law, namely Nazhir for waqf land and the subject of the right of management for land with the right of management.

Legally speaking, in analysing the differences between waqf land and land with the right of management, the author finds out that waqf land, land rights can also be given with the right of management as well. Based on these similarities, the innovation of granting land rights on waqf lands as discussed in this article.

\section{Procedures for Granting Land Rights on Waqf Land}

If the concept of granting land rights on waqf land can later be applied, it can refer to the provisions for granting land rights over management rights. Requirements for granting land rights on the right of management are currently regulated in Government Regulation Number 18 of 2021. The right of management that are to be granted or cooperated with other parties (third parties) can be granted with the right of cultivation, right of building, or right of use. The right of management holders and third parties in the context of granting land rights must make a land-use agreement.

The land-use agreement must at least contain:

a. The identity of the parties.

b. Location, boundary, and land area.

c. The type of use, utilization of land, or buildings to be erected.

d. Provisions regarding types of rights, period, extension, renewal, transfer, assignment, change, and cancellation/cancellation of rights granted on land with right of management, and provisions for ownership of land and buildings after the expiration of land rights. 
e. The amount of the the amount of the annual mandatory money and the method of payment.

f. Terms and conditions that bind the parties, implementation of development, fines for default including sanction clauses, and cancellation/termination of the agreement.

A land-use agreement can be an agreement from the holder of right of management to give part of his land with a land right. After the land utilization agreement is made, it must be registered with the land office to issue land rights certificates.

The implementation of granting land rights on the right of management can be a reference for the practice of granting land rights on waqf land. This is due to the similarity of legal aspects between waqf land and land with right of management as described above. However, it would be better if this concept could be applied in Indonesia one day, then a stronger legal basis is made for its implementation.

\section{Potential of Innovation Implementation on Waqf Land}

The recommendation for the granting of land rights on waqf land has several advantages or benefits if applied in Indonesia as Indonesia has the largest Muslim population in the world. The use of waqf is very potential for the welfare of the community. Apart from waqf institutions, Islam recognizes other institutions such as alms, infaq, and zakat. The position of waqf also exists as a form of Islamic concern of the welfare for the people.

In general, the benefits of waqf can be seen and depend on the management system. Traditional and modern management provide different benefits. Both do provide benefits, but the impact of these benefits is believed to have striking differences. Traditional management that puts the immutability of things in the top position often overrides management innovation. Meanwhile, modern management is considered for prioritizing aspects of the usefulness of objects through productive management while maintaining the existence of the object that is still there and does not decrease. So the substance of waqf does not lie solely in the maintenance of the object (waqf assets), but much more important is the value of the benefits of the object in helping to solve the economic problems of the people.

In particular, the concept of regulating land rights on waqf land is an innovation in the use of waqf lands in the context of developing productive waqf investments. The implementation of land rights on waqf land can provide benefits to the third parties as well as to the nazhir. The potential benefits for third parties who wants to claim rights on waqf land are: (a) freedom in relatively high land acquisition costs if they go through the land acquisition process for commercial purposes; and (b) additional capital if needed because it can guarantee land rights on waqf land with mortgage institutions subject to Nazhir's permission as waqf land manager. On the other hand, nazhir as the manager of waqf land can also benefitting from the waqf. This concept $\mathrm{s}$ also provides benefits in the form of (a) 
getting income from the cost of using waqf land, which must be paid in advance by a third party when they want to get land rights on waqf land; (b) get income from the cost of recommendations given by third parties when they want to extend their land rights; and (c) annual mandatory fee that a third party must pay to nazhir land. The funds obtained by nazhir from third parties can be used for the public interest and the welfare of the people according to the intention or the waqf pledge made by the waqif.

\section{CONCLUSION}

Waqf land can actually be converted into a productive waqf asset rather than a consumptive one. One of the alternative options for productive waqf land is the granting of land rights on waqf land. Waqf land and land with the right of management have some similarities in legal aspects. Therefore, this innovation in its application will be able to apply regulations regarding the granting of land rights on the right of management. The benefits that can be obtained from applying this innovation can be seen from the side of third parties and the side of nazhir. Third parties benefit from the freedom of land acquisition costs which are relatively expensive and can guarantee land rights to obtain additional capital.

On the other hand, nazhir can receive benefits in the form of land use fees, recommendation fees, and annual mandatory fees that must be paid by the holder of land rights on waqf land. These benefits can be used for the public interest to create the welfare of the people according to the waqf pledge deed. As an innovation, it requires the support and participation of policymakers such as the government of the Republic of Indonesia, the Indonesian House of Representatives, and the Indonesian Waqf Board to issue a practical legal basis for the application of this innovation.

\section{REFERENCES}

Faizin, F., \& Nuryatin, A. (2017). Religiusitas dalam Syair-Syair Tegalan Karya Imam Chumedi. Seloka: Jurnal Pendidikan Bahasa Dan Sastra Indonesia, 6(1), 100-110.

Harsono, B. (2016). Indonesian Agrarian Law, History of the Formation of Basic Agrarian Laws, Content and Implementation.

Hidayati, Tri. (2012). "Abandoned Waqf Land: Perspective of PP Number 11 of 2010." Journal of Islamic Studies p. 211-231.

Hutagalung, Arie S. and Oloan Sitorus. (2011). About Right of Management. Yogyakarta: STPN Press.

Indonesia. Basic Agrarian Law. Law Number 5 of 1960, State Gazette Number 1960 - 104, Additional State Gazette Number 2043.

Indonesia. Government Regulation concerning Right of Management, Land Rights, Flat Units, \& Land Registration. Government Regulation Number 18 of 2021.

Indonesia. Job Creation Law. Law Number 11 of 2020, State Gazette Number 245 of 2020, Additional State Gazette Number 6573.

Indonesia. Waqf Law, Law Number 41 of 2004, State Gazette Number 159 of 2004, Additional State Gazette Number 4459. 
Islam, M. Z. (2013). Legal enforceability of ADR agreement. International Journal of Business and Management Invention, 2(1), 40-43.

Jalil, M. A., Islam, M. Z., \& Islam, M. A. (2020). RISKS AND OPPORTUNITIES OF GLOBALIZATION: BANGLADESH PERSPECTIVE. Journal of Asian and African Social Science and Humanities, 6(4), 13-22.

Malaysia. National Land Code. Act Number 56 of 1965.

Moleong, Lexy J. (2017). Qualitative Research Methodology. Bandung: Remaja Rosdakarya.

Munawwir, Ahmad Warson. (1984). Al-Munawwir Arabic-Indonesian Dictionary. Yogyakarta: Unit for Procurement of Religious Scientific Books at AlMunawwir Islamic Boarding School.

Prihatini, Farida et. al. (2005). Islamic Law of Zakat and Waqf Theory and Practice in Indonesia. Depok: Publishing Agency of the Faculty of Law, University of Indonesia.

Santoso, Urip. (2017). Land Rights, Right of Management, and Ownership Rights to Flat Units. Depok: Kencana.

Soekanto, Soerjono. (1986). Introduction to Legal Research. Jakarta: University of Indonesia Publisher.

Sumanto, Listyowati and Siti Nurbaiti. (2013). "Comparison of Legal Types of Land Rights in Indonesia, Malaysia, and Singapore." Research Journal and Scientific Work Trisakti University Research Institute 25, p. 25-56.

Sumardjono, Maria S.W. (2008). Land in the Perspective of Economic, Social and Cultural Rights. Jakarta: Kompas Publisher.

The National Commitee on Sharia Finance. (2019). "Exploring the Potential of the E-Waqf Exchange as a Source of Financing for Sustainable Development Goals (SDGs)." Insight: Sharia Economics Bulletin 4, p. 15-16. 